\title{
UM NOVO CONCEITO PARA PARQUE URBANO NO BRASIL DO SÉCULO XXI
}

\author{
A NEW CONCEPT FOR URBAN PARK IN BRAZIL ON THE $21^{\text {ST }}$ CENTURY
}

\author{
Francine Gramacho Sakata \\ Fabio Mariz Gonçalves
}

\begin{abstract}
RESUMO
Este artigo visa mostrar que os parques urbanos implantados entre 2000 e 2017 em grandes cidades brasileiras são diferentes dos implantados no século XX, e criaram novos desafios de desenho e de gestão. Os grandes parques do século $X X$ se destinavam ao lazer das massas urbanas e eram feitos em áreas centrais ou de moradia de camadas de rendas mais altas. Os novos parques, em boa parte, foram feitos com menos ênfase na provisão de lazer mas, sobretudo, pensando na conservação ambiental, e estão locados em bairros menos centrais ou de camadas de rendas mais baixas. $\mathrm{O}$ artigo se desenvolve a partir do trabalho de Sakata, que identificou os parques existentes em 14 cidades, destacando aqueles criados entre 2000 e 2017. Os parques foram alocados em mapas de distribuição de renda, e dados sobre os mais recentes foram coletados em sites das prefeituras, em imagens do Google Earth, em artigos de jornais, nos relatórios das oficinas realizadas pelo grupo de pesquisa Quadro do Paisagismo no Brasil - Sistemas de Espaços Livres (Quapá-SEL) e em outros trabalhos. Conclui-se que, ainda que os grandes parques tradicionais sejam a referência para os projetistas e a população, a maioria dos novos parques, criados principalmente a partir de demandas pela preservação ambiental, está inserida em contextos muito diferentes daqueles dos parques tradicionais e, por isso, apresenta outras demandas de uso. É conveniente, assim, rever e ampliar o conceito de parque urbano para abarcar essas novas figuras, mas é preciso, principalmente, reavaliar os critérios de desenho para os novos parques e incrementar a gestão de todo o conjunto.
\end{abstract}

Palavras-chave: Parque Urbano. Parque Público. Paisagismo. Preservação Ambiental.

\section{ABSTRACT}

This article has the objective to show that urban parks established between 2000 and 2017 in Brazilian cities are different from the parks of the twentieth century and have created new design and management challenges. The great parks of the twentieth century were intended for the leisure of the urban masses and were made in central or housing areas of higher income segments. The new parks, to a large extent, were made with less emphasis on leisure provision but above all, on environmental conservation and are located in less-central neighborhoods or lower-income camps. The article develops from the work of Sakata (2018) that identified the existing parks in 14 cities and highlighted those created between 2000-2017. The parks were leased on income distribution maps and data were collected on the latest on city hall websites, GoogleEarth images, newspaper articles, the reports of the Workshops conducted by the Quapá-SEL research group and other surveys. Although the large traditional parks are the reference for the designers and the population, most of the new parks, created mainly from demands for environmental preservation, are inserted in contexts that are very different from those of the traditional parks and, therefore, they present other demands of uses. It is appropriate to review and extend the concept of urban park to cover these new figures, but mainly, it is necessary to re-evaluate the design criteria for the new parks and to increase the management of old and new ones.

Keywords: Urban park. Public Park. Landscaping. Environmental Preservation. 


\section{INTRODUÇÃO}

Entre 2000 e 2017, o número de parques urbanos brasileiros dobrou, se considerarmos um conjunto de 14 capitais, relacionadas na Tabela 1 (SAKATA, 2018). Essas capitais foram selecionadas por terem sido previamente investigadas pela rede de pesquisa Quadro do Paisagismo no Brasil - Sistemas de Espaços Livres (Quapá-SEL), que buscou caracterizar a morfologia urbana e os sistemas de espaços livres nas cidades através de oficinas com a participação conjunta de pesquisadores da Faculdade de Arquitetura e Urbanismo da Universidade de São Paulo (FAUUSP) e de universidades locais. Nessas importantes cidades brasileiras, foram contados 205 parques até o ano 2000. De 2000 a 2017, surgiram novos 240 parques - áreas públicas nomeadas e, ainda que minimamente, conformadas como tal. Esse processo não foi significativo, em termos numéricos, em algumas grandes cidades litorâneas - como Rio de Janeiro, Maceió, Santos, Fortaleza e Florianópolis -, por a orla da praia ainda ser o grande parque urbano, acolhendo grande diversidade de usos sociais, tanto na areia quanto no calçadão. Mas foram feitas, nesse período, obras de ampliação e requalificação dos espaços de lazer nas orlas dessas cidades. Vitória e Recife são exceções, com a criação de parques novos. Nas capitais interiores - como São Paulo, Belo Horizonte, Brasília, Campo Grande, Curitiba e Rio Branco, e em grandes cidades como Guarulhos, Sorocaba e São José dos Campos, o fenômeno da criação de novos parques foi evidente. Em Goiânia, um dos expoentes desse processo, até 1996 havia três parques implantados e, em 2016, são 39 parques e bosques equipados que podem ser utilizados pela população, de um total de 190 áreas reservadas para essa finalidade, mas que até 2018 não haviam sido estruturadas como parques públicos.

Para estudar esse processo, foram levantados os dados disponíveis sobre os parques das cidades em sites das prefeituras e de outras organizações, em artigos de jornais e nos relatórios das oficinas realizadas pelo grupo de pesquisa Quapá-SEL. As prefei- turas e governos estaduais nem sempre comunicam suas ações de forma direta. Seis parques inaugurados em Curitiba na gestão administrativa anterior, por exemplo, não constavam no site da prefeitura em 2018.

Os parques foram buscados no Google Earth e Street View, também para verificar se poderiam ser reconhecidos como parques públicos, e foram locados em mapas de morfologia urbana e em mapas de distribuição de renda produzidos pelo Quapá-SEL em ArcGIS. A questão da renda foi importante para nós porque os primeiros parques foram feitos nos bairros das elites com a função de lazer e embelezamento mas, principalmente, de valorizar os imóveis no entorno. Imaginávamos que isso seria uma constante, mas observamos que, na recente leva de criação de parques, o principal motor na locação dos parques não foi a valorização imobiliária, mas a oportunidade do poder público de aproveitar áreas para preservação ambiental e lazer urbanos.

Parques de conservação envoltos pela área urbana e abertos à fruição foram frequentemente incluídos na listagem, exceto casos como os das prefeituras do Rio de Janeiro e de Porto Alegre, em que a classificação é mais clara e distingue parques naturais dos parques urbanos. Mas, na prática, não distinguem o parque urbano do parque de conservação em meio urbano: ambos são parques urbanos. Foram desconsiderados os parques sem acesso público, sempre que identificados. Também não foram somados os calçadões de praias, ainda que funcionem como parques urbanos.

A área dos parques, na Tabela 1, não representa a soma das áreas protegidas, mas das áreas de parques no município com acesso público. A soma das áreas totais dos parques com uso público não é uma informação de grande significado porque esse número não nos informa se a população tem acesso fácil a essas áreas, nem se têm qualidade de fato para o lazer. Para a fruição pública, pequenos parques bem mantidos podem ser muito úteis e grandes parques podem ser desconhecidos. Assim, o dado que destacamos é o número de novos parques abertos. 
Para compreender os motivos que levaram à criação dos novos parques, foram analisadas as formas como o poder público os anunciava e a presença do discurso ambiental. Observou-se que discurso ambiental foi utilizado em todas as apresentações de parques, mesmo daqueles mais construídos e com reduzida área vegetada. Apenas um parque, o Parque dos Esportes Radicais em São Paulo, foi apresentado unicamente como equipamento para atividades esportivas e recreativas. Todos os demais foram, ao menos em discurso, lançados como ações de meio ambiente. Foi, então, feita a relação da criação de parques com a evolução da legislação e das instituições de proteção ambiental no período. Essa evolução não aconteceu de forma similar em todos os estados e cidades, mas contribuiu para consolidar o resultado.

\section{LocAlizAÇÕ̃es}

Os parques criados entre 2000 e 2017 não estão preferencialmente implantados nas localizações das camadas de alta renda e sua distribuição pelo tecido urbano é dispersa. Eles foram locados tanto em bairros de rendas mais altas quanto de rendas mais baixas, sem relação com a densidade populacional. Isso pôde ser observado nas cidades pesquisadas, como demonstram os mapas de Belo Horizonte e Campo Grande (Figuras 1 e 2).

Os parques com equipamentos de maior qualidade, melhor manutenção e com afluxo de público de vários extratos de renda seguem sendo aqueles instalados nos bairros de população de renda mais alta. Mas constatou-se que os novos parques foram abertos indistintamente pelo tecido urbano, geralmente onde havia recursos naturais a preservar e onde houve um conjunto de oportunidades que viabilizaram a criação naquele local.

Em São Paulo, o Programa Cem Parques - conduzido pela prefeitura entre 2008 e 2012 - buscou ampliar o número de parques na cidade e o fez principalmente em locais nos quais as oportunidades convergiam: terrenos que já eram de posse do poder público, em geral com bosques ou nascentes a preservar, e projetados e implantados conforme afluíam recursos de termos de compromisso para compensação ambiental de outros empreendimentos pela cidade (Figura 3).

\subsection{LOCALIZAÇÕES E TRANSFORMAÇÕES URBANAS}

Grandes mudanças aconteceram no país no início do século XXI. As médias e grandes cidades brasileiras ficaram mais construídas uma vez que o número de domicílios cresceu ainda mais que a população. Na região metropolitana do Rio de Janeiro, por exemplo, o crescimento do número de domicílios entre 2000 e 2010 foi de 20,1\%; o da população, $9 \%$. Isso significou um quinto das casas ou apartamentos acrescidos na cidade. Esse aumento do número de domicílios se deve especialmente à nova composição das famílias, que é menor. Para uma década, é um crescimento expressivo 1 .

A pesquisa Quapá-SEL do Laboratório da Paisagem FAUUSP investigou as transformações nas cidades brasileiras no início do século XXI (PEGORARO, 2017; RIBEIRO, 2018), diferenciando três processos: (1) transformações por substituição, quando a volumetria construída foi alterada: ampliada, trocada por outra ou demolida; (2) transformação por consolidação, quando áreas vazias foram construídas dentro dos tecidos urbanos; e (3) transformação por adição, quando áreas não urbanas foram incorporadas à mancha urbana.

As transformações por substituições são características dos centros expandidos e áreas consolidadas. Há a tendência de as construções horizontais serem substituídas por prédios, mas a substituição pode ser por outro tipo edificado, não necessariamente pelos verticalizados. Pelos levantamentos do Quapá-SEL, essas transformações ocorreram em menor quantidade no período analisado, se comparadas às outras, geralmente dentro do intervalo de $5 \%$ a $15 \%$ do total transformado. A consolidação fol

1 De 2000 a 2010, os domicílios passaram de 3.284 .446 para 3.944.171 e a população de 10.925.422 para 11.903 .349 (um incremento de 659.725 domićlios). Dados coletados por João Meyer para a Oficina Quapá-SEL II do Rio de Janeiro (CUSTÓDIO, 2016). 
Tabela 1 - Quantidade de parques existentes até 2000 e criados entre 2000-2017.

\begin{tabular}{|c|c|c|c|c|c|c|c|c|c|}
\hline 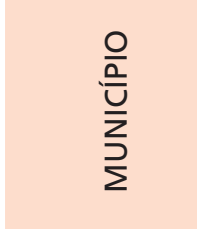 & 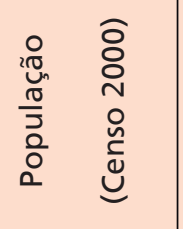 & 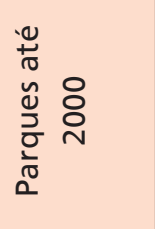 & 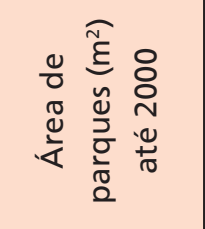 & 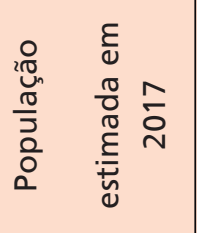 & 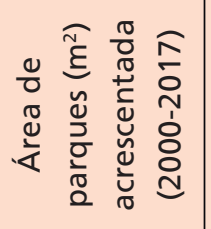 & 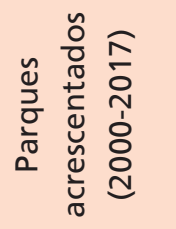 & 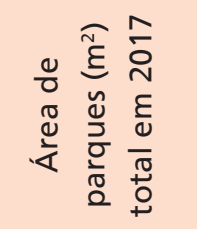 & 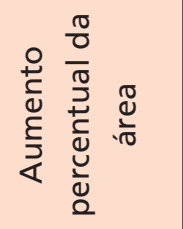 & 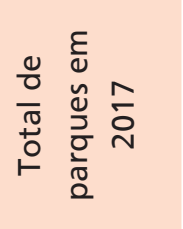 \\
\hline SÃO PAULO & 10.434 .252 & 40 & 26.112 .671 & 12.106 .920 & 8.893 .204 & 76 & 35.005 .821 & $34 \%$ & 116 \\
\hline $\begin{array}{l}\text { BELO } \\
\text { HORIZONTE }\end{array}$ & 2.238 .526 & 29 & 4.842 .266 & 2.523 .794 & 2.893 .647 & 33 & 7.735 .913 & $60 \%$ & 62 \\
\hline GOIÂNIA & 1.093 .007 & 3 & 301.130 & 1.466 .105 & 5.188 .953 & 39 & 5.490 .083 & $1.723 \%$ & 42 \\
\hline $\begin{array}{l}\text { DISTRITO } \\
\text { FEDERAL }\end{array}$ & 2.051 .146 & 21 & 32.159 .489 & 3.039 .444 & 86.544 .338 & 12 & 118.703 .827 & $269 \%$ & 33 \\
\hline VITÓRIA & 292.304 & 8 & 2.579 .129 & 363.140 & 469.259 & 5 & 3.048 .388 & $18 \%$ & 13 \\
\hline CURITIBA & 1.587.315 & 30 & 18.045 .935 & 1.908 .359 & 10.069 .685 & 22 & 28.115 .620 & $56 \%$ & 52 \\
\hline $\begin{array}{l}\text { CAMPO } \\
\text { GRANDE }\end{array}$ & 663.621 & 4 & 1.744 .261 & 874.210 & 5.654 .832 & 13 & 7.399.093 & $324 \%$ & 17 \\
\hline MANAUS & 1.405 .835 & 1 & 420.500 & 2.130 .264 & 855.220 & 13 & 1.275 .720 & $203 \%$ & 14 \\
\hline RECIFE & 1.422 .905 & 9 & 618.138 & 1.633 .697 & 3.380 .766 & 5 & 3.998 .904 & $547 \%$ & 14 \\
\hline $\begin{array}{l}\text { RIO DE } \\
\text { JANEIRO }\end{array}$ & 5.857 .904 & 30 & 59.308 .996 & 6.520 .266 & 47.817 .660 & 12 & 107.126 .656 & $81 \%$ & 42 \\
\hline SALVADOR & 2.443 .107 & 9 & 6.320 .000 & 2.953 .986 & 920.000 & 3 & 7.240 .000 & $15 \%$ & 12 \\
\hline FORTALEZA & 2.141 .402 & 6 & 139.217 & 2.627 .482 & 11.570 .000 & 2 & 11.709 .217 & $8.311 \%$ & 8 \\
\hline BELÉM & 1.280 .614 & 4 & 14.137 .000 & 1.452 .275 & 86.000 & 2 & 14.223 .000 & $0,6 \%$ & 6 \\
\hline $\begin{array}{l}\text { PORTO } \\
\text { ALEGRE }\end{array}$ & 1.360 .590 & 11 & 2.727 .600 & 1.484 .941 & 370.600 & 3 & 3.098 .200 & $14 \%$ & 14 \\
\hline TOTAL & 34.272 .528 & 205 & 169.456 .332 & 38.561 .089 & 190.114 .164 & 240 & 360.170 .442 & $112 \%$ & 445 \\
\hline
\end{tabular}

Fonte: Produzida por Francine Sakata e Caroline Ribeiro em 2018, com base em dados do IBGE (para a população) e dados das prefeituras, levantamento no Google Earth e outras fontes (para os parques). 
Figura 1 - Mapa de locação dos novos parques em Belo Horizonte.

Fonte: Sakata (2018).

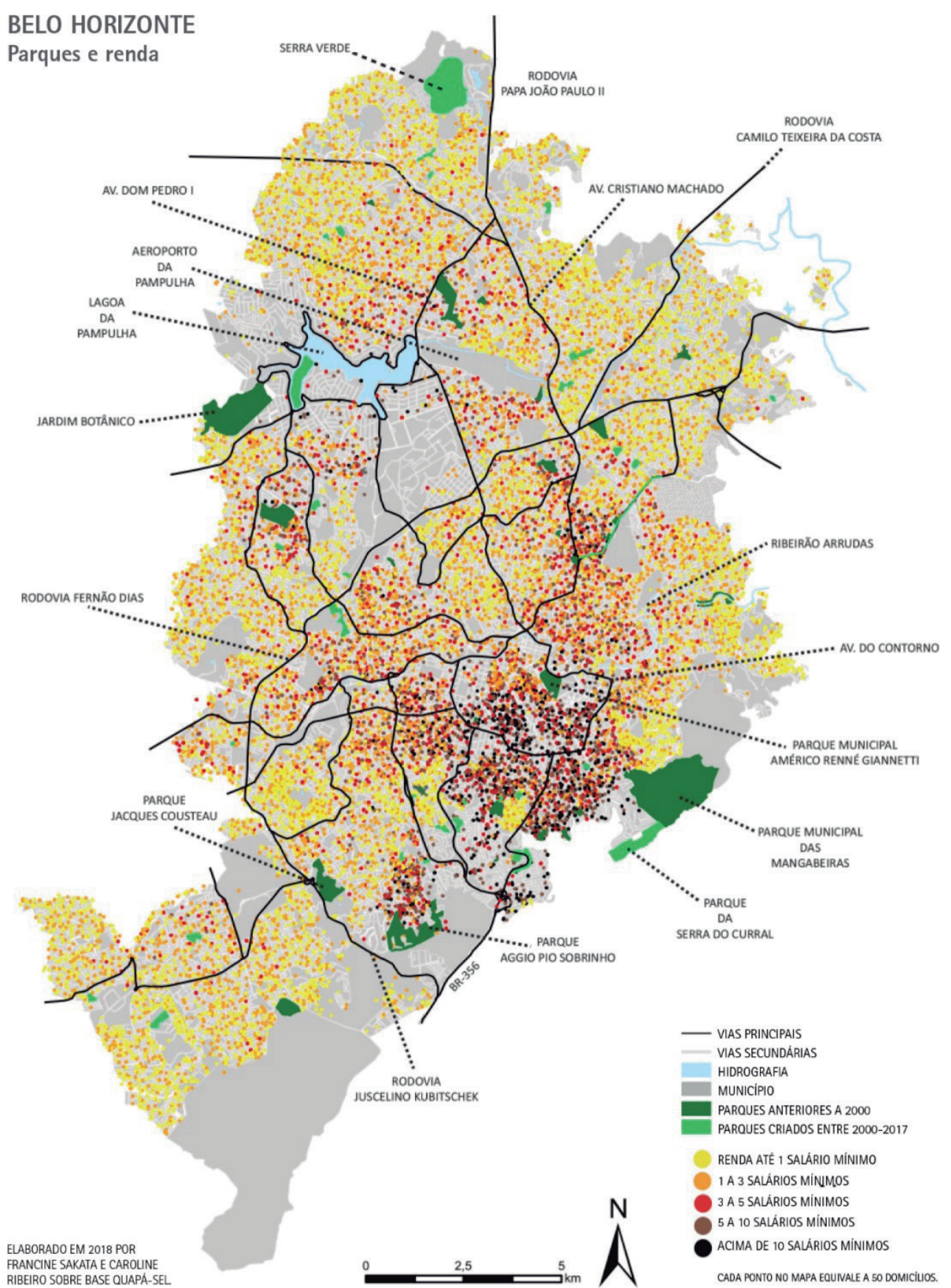


CAMPO GRANDE

Parques e renda

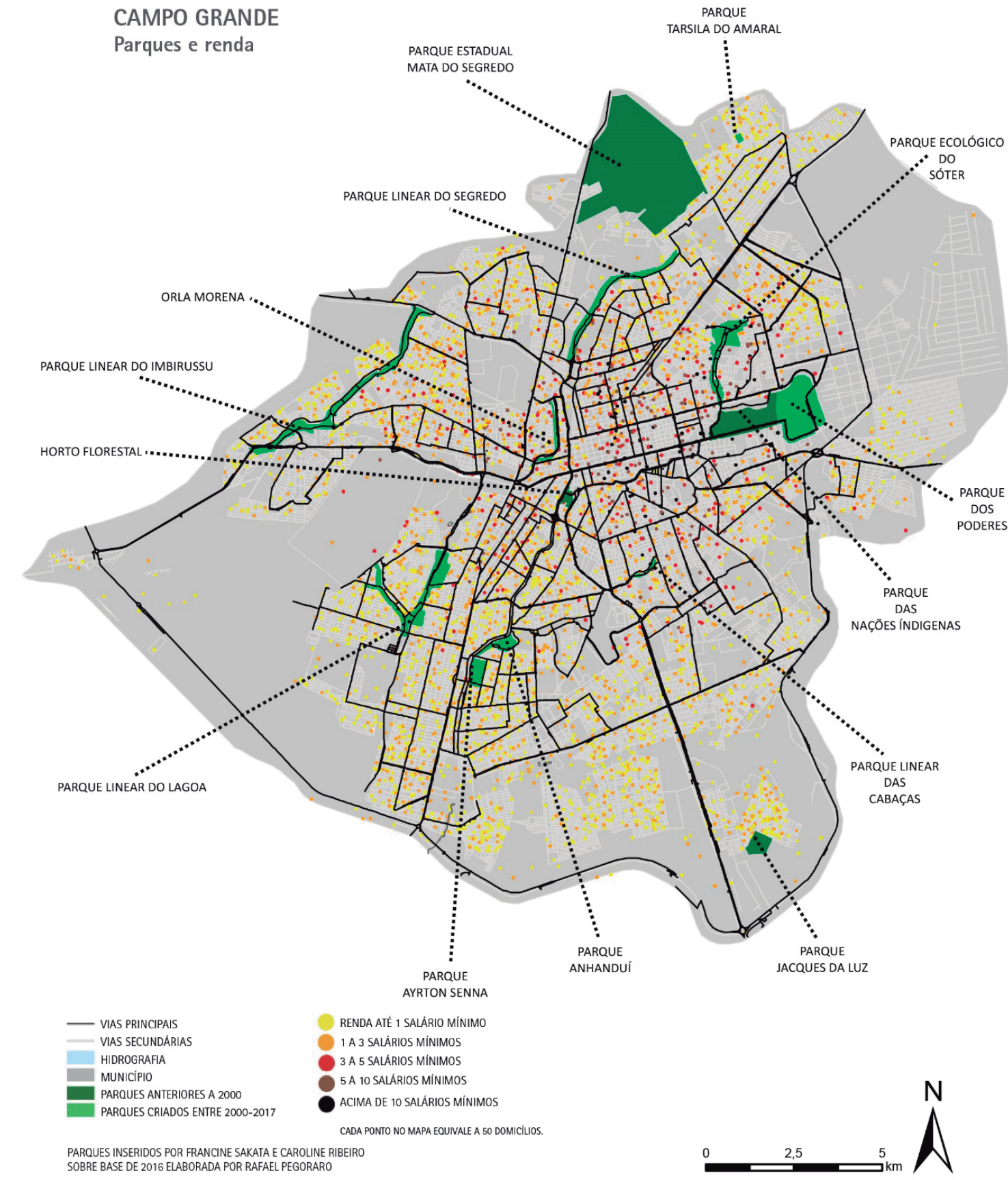

Figura 2 - Mapa de locação dos novos parques em Campo Grande. Fonte: Sakata (2018) 


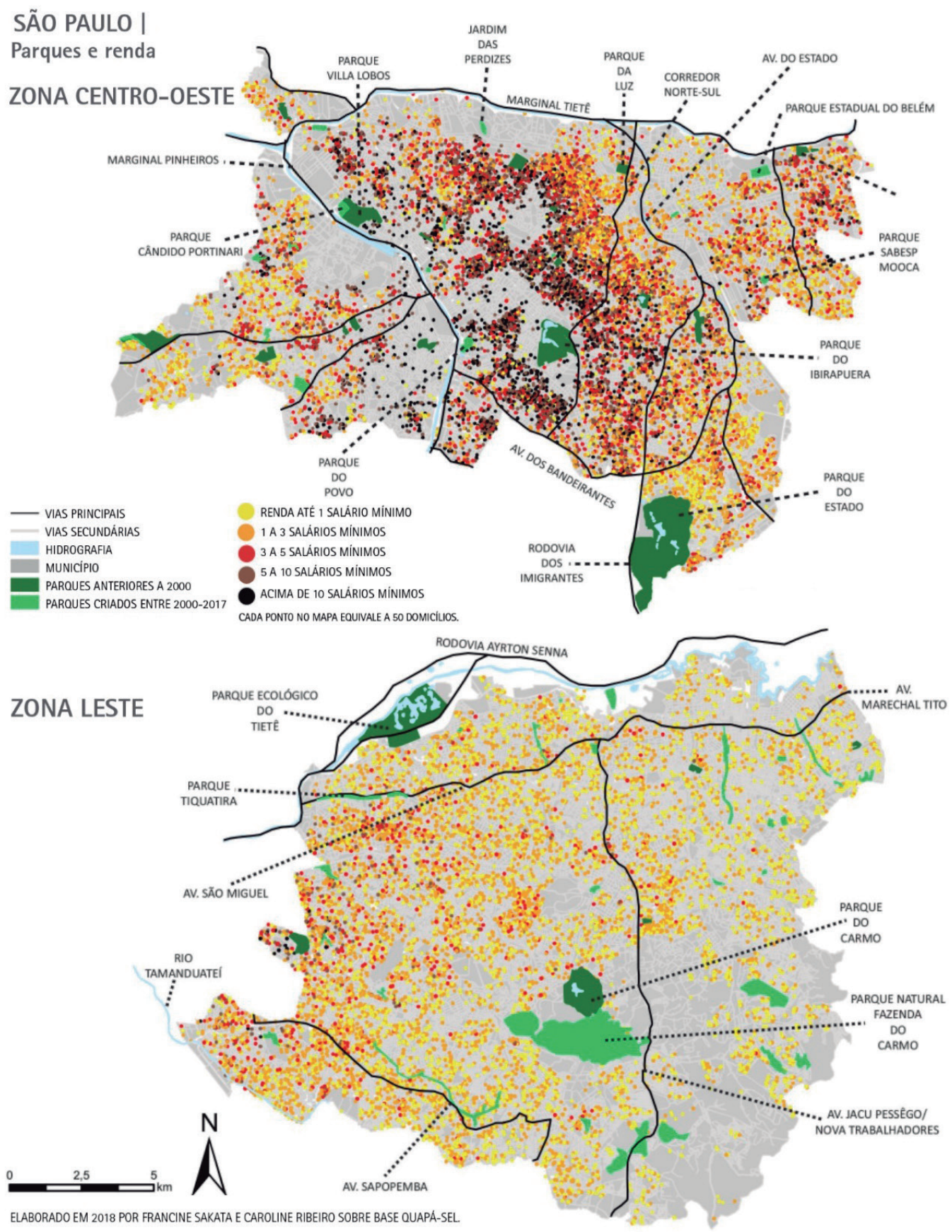

Figura 3 - Mapas de locação dos novos parques nas zonas Centro-Oeste e Leste de São Paulo. Fonte: Sakata (2018).

ELABORADO EM 2018 POR FRANCINE SAKATA E CAROLINE RIBEIRO SOBRE BASE QUAPA-SEL. 
o fenômeno mais observado e caracterizou-se nas cidades analisadas, principalmente pela construção de edificações de pequeno porte e edifícios em lotes vazios, adensando bairros preexistentes (RIBEIRO, 2018).

Por meio dos estudos da pesquisa Quapá-SEL, notou-se que as transformações por adição são comuns nas bordas das manchas urbanas, onde foram implantados muitos dos novos parques do período. Nas regiões metropolitanas, ultrapassam os limites dos municípios-sede, estendendo-se a territórios de municípios vizinhos. O fato de maior destaque nas periferias foi a extensa construção de conjuntos habitacionais de baixa renda associada ao Programa Minha Casa Minha Vida (MCMV), que buscou equacionar o déficit habitacional reprimido e marcou de forma permanente várias das paisagens urbanas brasileiras. Identificaram-se, também, áreas expressivas nas regiões metropolitanas ocupadas por loteamentos fechados de rendas médias e altas, com casas amplas e piscinas, que surgem próximos das rodovias. São grandes glebas muradas que geram descontinuidades no tecido urbano - isso é, não é possível cruzá-las.

As ocupações irregulares, caracterizadas pela precariedade construtiva e ausência de infraestrutura básica continuaram presentes, porém com menor ocorrência. Muitas ocupações ilegais passaram a ser planejadas, atendendo a parâmetros urbanísticos, visando à possível regularização futura.

Quando os mapas de criação de parques foram sobrepostos aos mapas de transformações nas cidades de Goiânia (Figura 4), Brasília (Figura 5) e Curitiba (Figura 6) observamos que parques foram criados em variadas localizações, independente das transformações urbanas pelas quais essas áreas passam.

Nas bordas das cidades, no contexto dessa expansão fragmentada, entre tecidos urbanos de conjuntos habitacionais, loteamentos fechados e invasões, os espaços livres são também fragmentados e frequentemente desqualificados. Nesses territórios, houve também a criação de parques, especialmente como reservas ambientais. Essa ação buscou resguardar porções ambientalmente valiosas das paisagens, agora incorporada às áreas urbanas. Os usos sociais desses parques ainda estão, em geral, por ser melhor definidos e estruturados.

\section{Papel da legislação Ambiental}

A ampliação da rede de parques de 2000 a 2017 foi impulsionada pela evolução da legislação ambiental. Podemos apontar três efeitos das leis de proteção ao meio ambiente nesse sentido: (1) o amparo que o sistema de unidades de conservação nacional deu à criação de unidades de conservação estaduais e municipais; (2) a criação de áreas de preservação permanente (APPs) que decretou como tais as margens de rios e lagoas, independente de serem áreas rurais ou urbanas; (3) a criação de instrumentos para captação de recursos de compensações ambientais para criar ou requalificar parques.

As intervenções públicas sistemáticas pela conservação ambiental no Brasil vinham ganhando corpo desde os anos 1980, com as primeiras disposições ambientais nacionais. Ao longo do tempo, os consensos sobre os recursos que deveriam ser preservados e de que forma isso poderia ser feito se ampliaram. Conforme o entendimento dos técnicos progredia, as administrações estaduais e municipais se aparelhavam com secretarias e colegiados de meio ambiente. As leis para amparar a preservação² evoluíram. Essa evolução jurídica não foi a mesma em todos estados e municípios mas, de forma geral, foram seguidas as diretrizes nacionais.

\subsection{UNIDADES DE CONSERVAÇÃO}

Em 2000, o Sistema Nacional de Unidades de Conservação (Snuc) estabeleceu 12 categorias de unidades de conservação que se diferenciam quanto à forma de proteção e aos usos permitidos. A lei partiu de figuras jurídicas já existentes, como Floresta $\mathrm{Na}$ cional, Parque Nacional, Estação Ecológica e Área de Proteção

\footnotetext{
2 A rigor, os termos conservação e preservação são distintos, cada um representando uma corrente amplamente discutida na área ambiental. Preservação quer dizer proteção integral sem interferência da ação humana e conservação significa proteção dos recursos naturais com utilização racional. Entretanto, a própria legislação brasileira nem sempre considera correto
} o uso desses termos. 
Figura 4 - Mapa de parques e transformações urbanas para Goiânia.

Fonte: Sakata (2018) com bases de Ribeiro (2018).

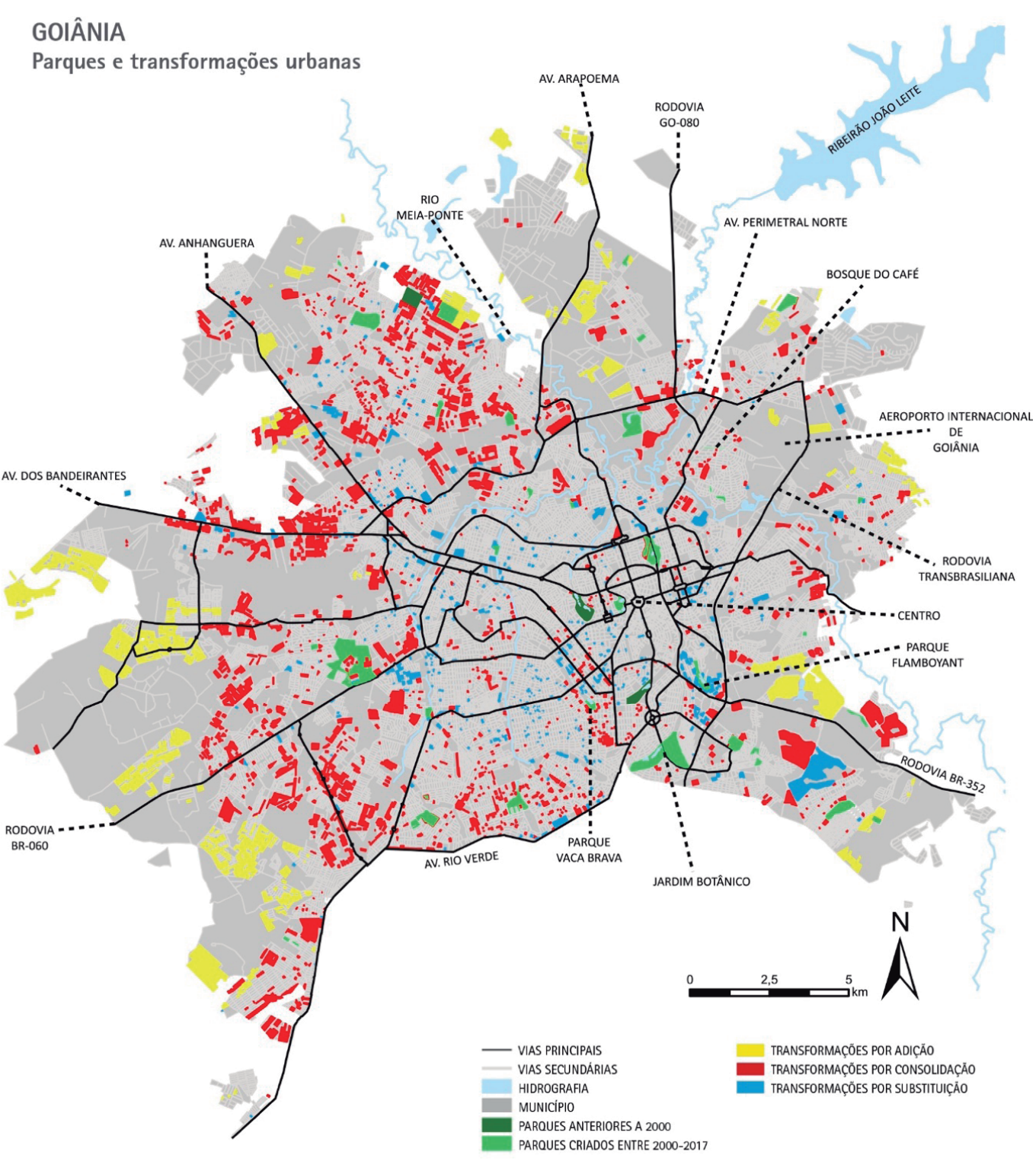

PARQUES INSERIDOS POR FRANCINE SAKATA E CAROLINE RIBEERO
SOBRE BASE DE 2018 ELABORADA POR VITOORA MENDES RBBEIPO 


\section{DISTRITO FEDERAL}

Parques e transformações urbanas

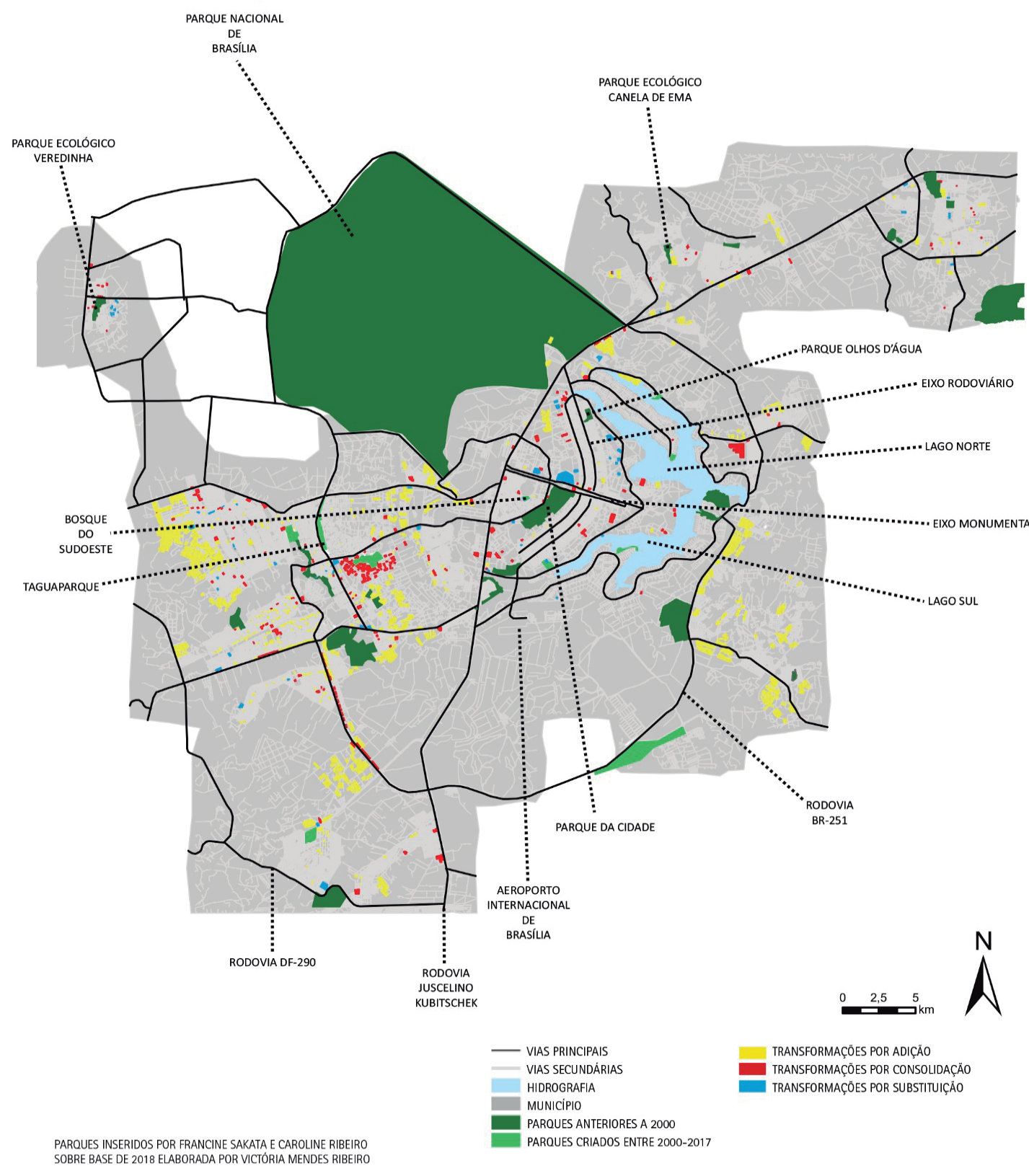

Figura 5 - Mapa de parques e transformações urbanas para Brasília.

Fonte: Sakata (2018) com bases de Ribeiro (2018) 
Figura 6 - Mapa de parques e transformações urbanas para Curitiba.

Fonte: Sakata (2018) com bases de Pegoraro (2017).

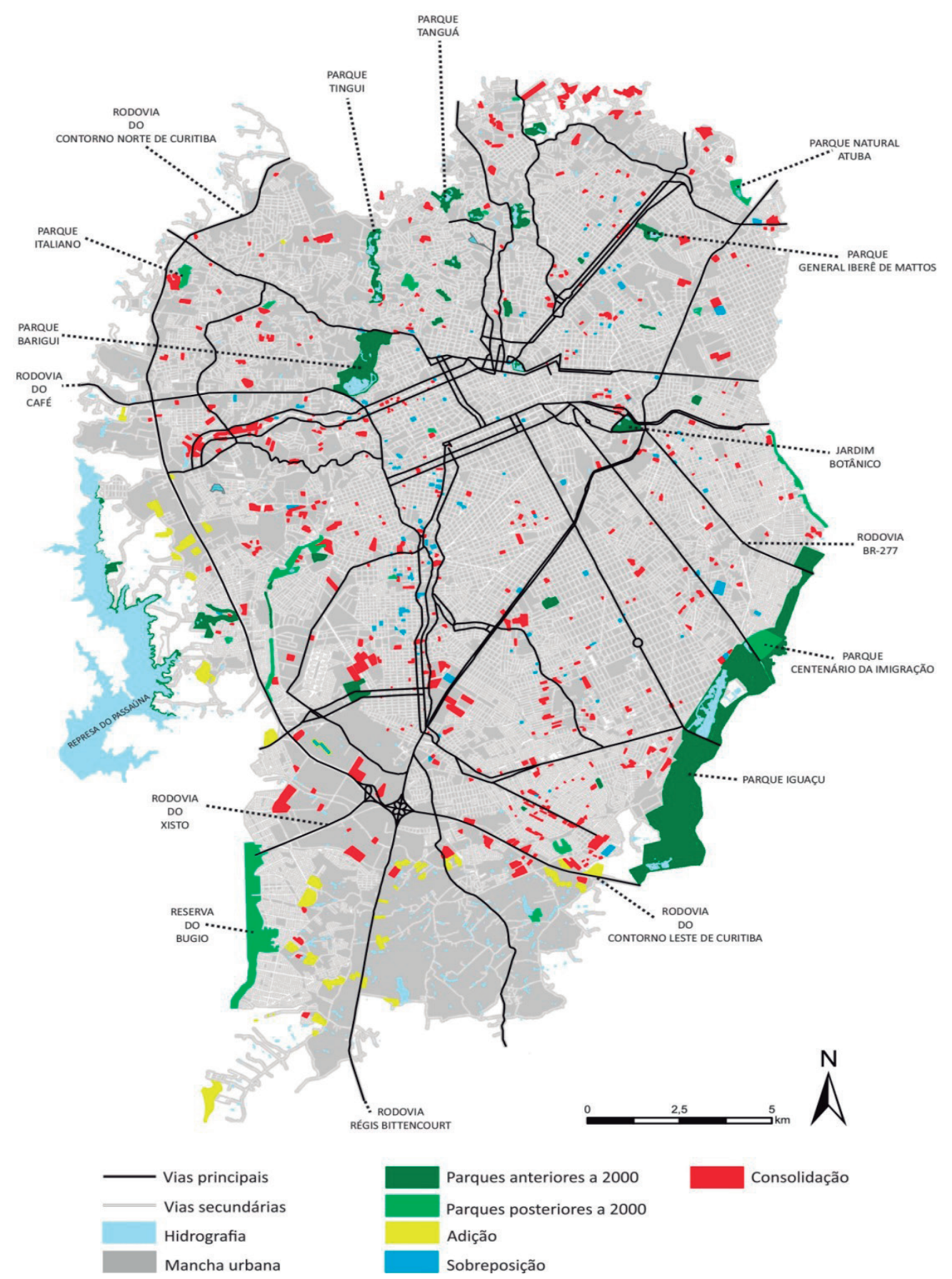


Ambiental (APA), e unificou a nomenclatura para todo o país. Há variações estaduais e municipais em função de unidades de conservação criadas e categorizadas anteriormente ${ }^{3}$.

Na cidade de São Paulo, por exemplo, já haviam sido criados parques estaduais com função primordial de proteção aos mananciais ou de remanescentes de vegetação, caso dos parques da Cantareira, Capivari-Monos, Fontes do Ipiranga e da Serra do Mar. O Parque Anhanguera, municipal, foi criado a partir de grandes áreas preservadas (Bartalini, 1999). O Plano Diretor de 2002 do município de São Paulo criou novas figuras no seu Sistema de Áreas Verdes, além dos tradicionais parques urbanos e praças públicas, tais como: áreas verdes públicas de proteção integral (parques e reservas); e áreas verdes públicas ou privadas de uso sustentável. Os parques foram hierarquizados em relação à sua função de barreira ao crescimento urbano e divididos em: (1) urbanos; (2) de beira de represa; (3) de amortecimento - funcionando como tampão de proteção entre uma unidade de conservação (UC) e o tecido urbano; (4) de contenção de ocupação - para amortecimento de áreas com forte pressão por ocupação4 4 Em torno da Represa de Guarapiranga, na Zona Sul da Cidade, foram criados parques (Figura 7) como o Linear São José (2007), Linear Castelo (2008) (Figura 8), Linear Nove de Julho (2008), Barragem do Guarapiranga (2008), Praia do Sol (2009) (Figura 9), o Cratera da Colônia (2007) e o Bororé (2012), esses dois últimos nunca abertos à visitação.

Na cidade do Rio de Janeiro, a Secretaria Municipal de Meio Ambiente (Smac) cadastrou como áreas protegidas: Área de Proteção Ambiental (APA), Área de Proteção Ambiental e Recuperação Urbana (Aparu), Área de Relevante Interesse Ecológico (Arie), Reserva Biológica, parque e bem natural tombado 5 . Para a prefeitura do Rio de Janeiro, parque é uma área protegida de posse e

3 Sobre a relação entre a legislação federal, estadual e municipal, cf. Souza (2018).

4 Projeto "Pesquisa e análise de aplicação de instrumentos em planejamento urbano ambiental no município de São Paulo". Produto 3. Relatório - Instrumentos de Planejamento Urbano-Ambiental do Sistema Municipal de Planejamento. São Paulo: LabHab/FAUUSP, SVMA junho de 2006. Mimeo. p. 25-28 (apud WHATELY et al., 2008).

5 A Portaria do Ministério do Meio Ambiente $n^{\circ} 245$, de 11 de julho de 2011, reconheceu o Mosaico Carioca, composto por 2 UCs federais, 4 UCs estaduais e 17 UCs municipais (RIO DE JANEIRO, 2010). domínio públicos, destinada à visitação e ao lazer. Quando criado pelo município, é denominado Parque Natural Municipal.

Em Vitória, município que tem sido pioneiro na institucionalização da proteção ambiental, uma das ações privilegiadas pela Secretaria Municipal de Meio Ambiente (Semmam) desde a sua implantação em 1986 está relacionada à criação de UCs e áreas verdes públicas. Inicialmente, não havia diferenciação entre as UCs e áreas verdes públicas, como os parques urbanos. Com o passar do tempo, o termo "parque urbano" passou a ser associado aos parques desprovidos de atributos ambientais, que não se enquadravam na legislação do Snuc ${ }^{6}$. Assim, o parque urbano, em Vitória, não é definido pelos usos de lazer, mas pela ausência de fragmentos naturais a proteger.

Em Fortaleza, a prefeitura definiu que, entre as áreas verdes, os parques urbanos conformam uma categoria cujo objetivo principal é a preservação e, em casos justificados, podem ser compatibilizados com a oferta de equipamentos e espaços de lazer urbano (FORTALEZA, 2014).

No Distrito Federal, a criação de parques também foi intensamente direcionada pela conservação. Na delimitação das áreas para parques, não se distinguiram as urbanas das não urbanizadas e o território foi considerado do ponto de vista dos recursos a conservar e - de forma alguma - não dos usos sociais e urbanos. Os parques urbanos foram classificados como parques ecológicos, que são uma categoria das UCs, assim como matas nativas, estações ecológicas e reservas biológicas. As malhas urbanas ora contornavam as áreas criadas para parques, ora não contornavam, e muitos não foram qualificados.

Parques naturais foram considerados, por todo o século $X X$, figuras distintas dos parques urbanos. Distantes das cidades, podiam ou não estar abertos à fruição humana. Há uma corrente de pensamento, com mais de um século nos Estados Unidos e que vem 6 A primeira área de proteção criada pelo município de Vitória foi a Estação Ecológica llha do Lameirão, em 1986, dando destaque à preservação do ecossistema do manguezal. Posteriormente, foi criado o Parque Municipal Gruta da Onça, em 1988. O município também se beneficiou com a criação do Parque Natural da Fonte Grande pela Assembleia Legislativa do estado do Espírito Santo que, depois da implantação do parque, transferiu sua responsabilidade à Secretaria Municipal (TRIGUEIRO; LEONARDO, 2011). 


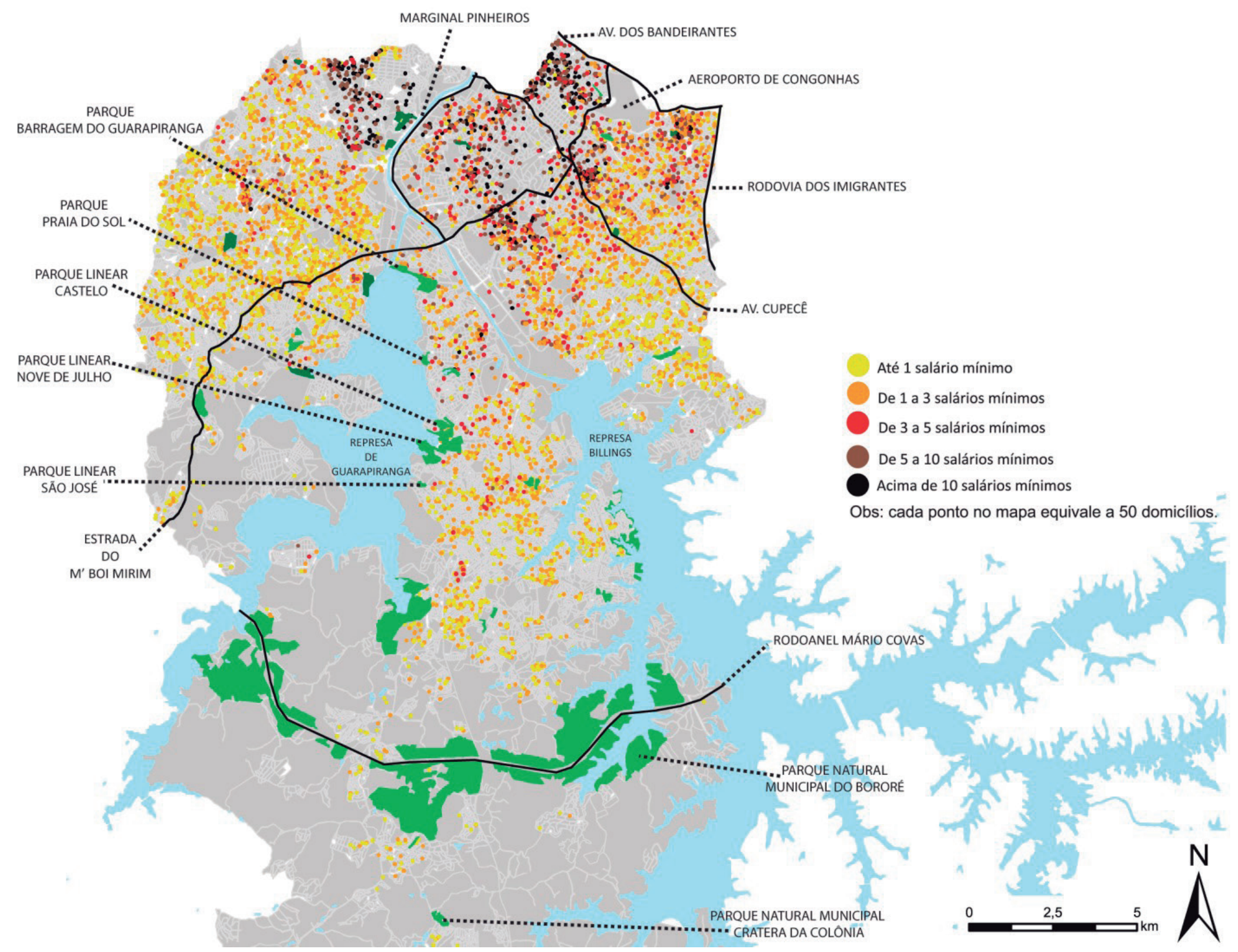

Figura 7 - Parques da Zona Sul de São Paulo.

Fonte: Elaborado por Caroline Ribeiro com base em Sakata (2018). 

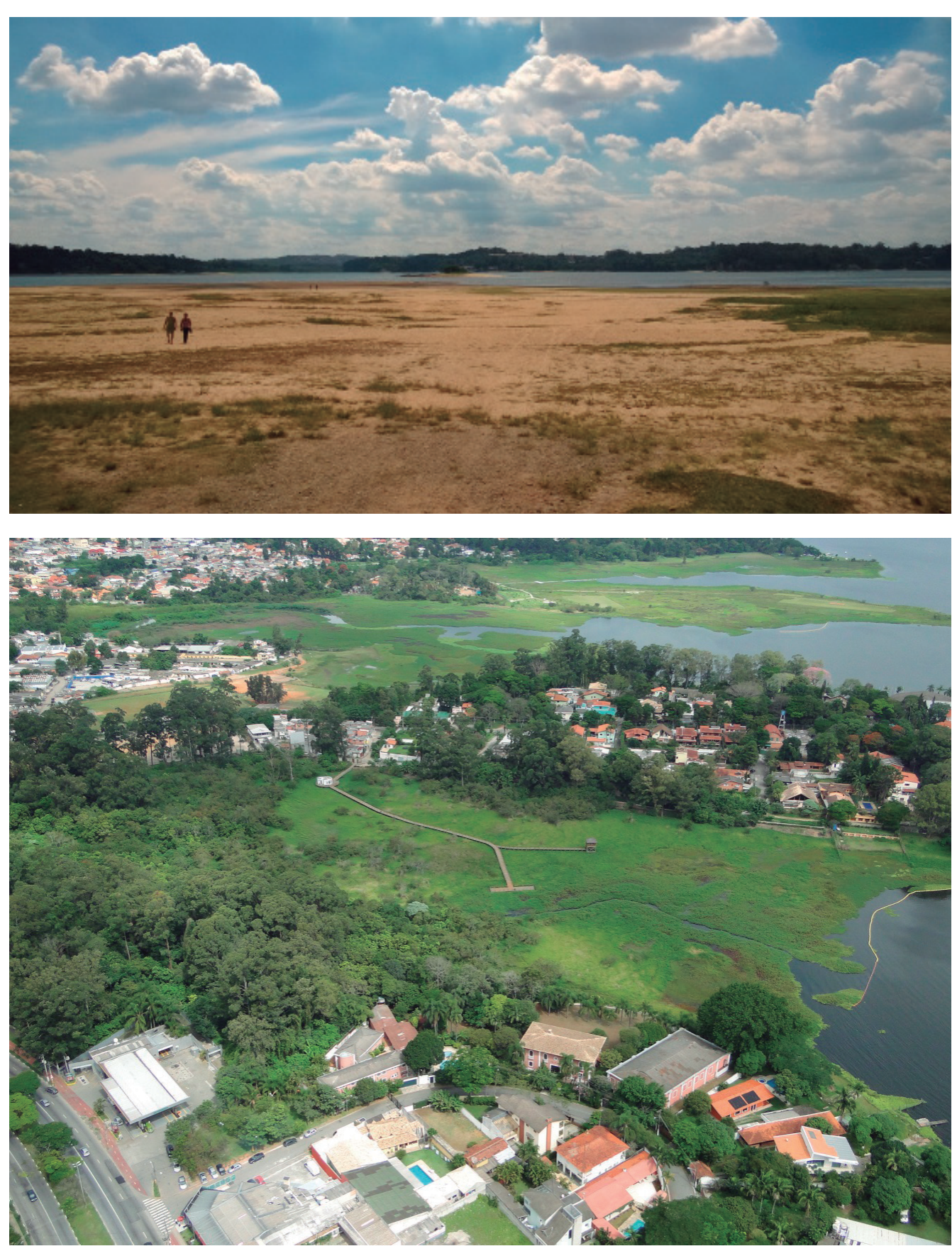

Figura 9: Praia do Sol. Foto: Caroline Ribeiro, 2015. 
ganhando impulso no Brasil, que valoriza o entendimento de que é importante que os parques naturais atraiam visitantes e sejam conhecidos para que obtenham recursos que garantam a preservação ${ }^{7}$. O Parque Nacional da Floresta da Tijuca, na cidade do Rio de Janeiro, por ser o mais conhecido dos parques nacionais, é também o mais vigiado, o que conta com mais funcionários e recebe mais recursos. Com a criação dos parques de conservação nos meios urbanos, sejam eles cercados total ou parcialmente pela malha urbana, temos parques urbanos. Assim, o conceito de parque urbano se misturou ao do parque natural, como vimos ocorrer em muitas cidades.

\section{2. Áreas de preservação ao longo de CURSOS D'ÁGUA}

O Código Florestal Brasileiro (BRASIL, 2012) considera Áreas de Preservação Permanente (APPs), entre outras, as faixas marginais de qualquer curso d'água natural perene e intermitente, excluídos os efêmeros, desde a borda da calha do leito regular, variando conforme a largura do curso d'água em questão, em torno de reservatórios naturais e artificiais, bem como as áreas no entorno das nascentes e dos olhos d'água perenes em um raio mínimo de 50 metros. Também é determinada a possibilidade simultânea de ocupação humana e preservação, por meio da utilização parcial da área total da APP pelo sistema de áreas verdes de domínio público, sendo liberados percentuais de impermeabilização do solo $(5 \%)$ e intervenção paisagística $(15 \%)$, com possível flexibilização em Zonas Especiais de Interesse Social segundo normas específicas. Galender e Campos (2014) entendem que essa postura permite apropriar essas áreas e, portanto, sua consolidação, o que significa um ganho, ao mesmo tempo, social e ambiental ${ }^{8}$.

Essa lei é genérica, isso é: não considera a história da cidade e os processos urbanos já em curso. As áreas decretadas como prote-

$7 \quad$ No Brasil, o Instituo Semeia tem promovido palestras e publicações com o intuito de fortalecer essa ideia e tem buscado alinhavar parcerias do setor público com o setor privado para que os parques naturais sejam incluídos no circuito econômico. Contam que, com isso, haverá mais recursos para assegurar a manutenção dos bens naturais.

8 Sobre esse tema, cf. Souza (2015). gidas podem ser públicas ou particulares. Podem ter sido ocupadas por avenidas ou por moradias de população de baixa renda. Sua conversão em parque pode não ser viável em curto prazo por fatores como: serem de propriedade particular, conflito com outros usos, falta de recursos ou falta de demanda para usos de lazer no local. Apesar disso, a médio e longo prazo, as APPs constituem um estoque de áreas reservadas para futuros parques.

Mesmo antes da lei das APPs, o entendimento de que a rede hídrica tem um papel na drenagem urbana e que respeitar as faixas marginais é uma forma de minimizar os prejuízos causados pelas inundações já incentivava a criação de parques associados aos cursos d'água, comumente denominados parques lineares.

\subsection{Recursos de licenciamento ambiental}

A figura do licenciamento ambiental foi apontada pela primeira vez pela Lei Federal 6.938/1981, que trouxe o conceito de responsabilidade objetiva, no qual o poluidor é obrigado a indenizar ou reparar os danos ao meio ambiente e a terceiros causados por sua atividade. Coelho (2008) monta esse quadro: em 1986, o Conselho Nacional do Meio Ambiente (Conama) consolidou o uso do Estudo de Impacto Ambiental (EIA) como principal ferramenta dos processos de licenciamento; em 1998, a Lei de Crimes Ambientais (IBAMA, 2014) potencializou a aplicação de compensações ambientais; em 2000, a Lei Federal n 9.985/2000 implantou o Sistema Nacional de Unidades de Conservação (Snuc); e em 2004, o Instituto Brasileiro do Meio Ambiente e dos Recursos Naturais Renováveis (Ibama) instituiu a Câmara Federal de Compensação Ambiental (CFCA), que foi um precedente para a abertura de câmaras de compensação nas esferas estadual e municipal, como no município de São Paulo.

Ainda que o estabelecimento de instrumentos que permitissem a transferência de recursos de licenciamentos ambientais para os órgãos de meio ambiente tenha se dado de modo diferente em cada estado e município, essas leis criaram o arcabouço que amparou municípios a aprovar ou não obras de médio e grande porte, aplicar sanções e capturar - por meio de multas - recursos 
de obras de infraestrutura ou de empreendimentos imobiliários. As verbas de Termos de Compensação Ambiental ou de Ajustamento de Conduta foram importantes, a partir dos anos 1990, para a criação e o aparelhamento de parques tanto em periferias como em bairros de altas rendas. A aplicação desses recursos em parques ocorreu mais em algumas cidades - como São Paulo, Vitória, Belo Horizonte e Goiânia - que em outras - como Porto
Alegre, Fortaleza ou Rio de Janeiro. Em Belo Horizonte, o Parque Nossa Senhora da Piedade (inaugurado em 2008), na região norte, foi criado através do Programa Municipal de Recuperação Ambiental (Drenurbs) em uma obra que envolveu desapropriações e remoções de famílias (Figura 10). Em Vitória, obras nas estruturas portuárias geraram verbas de compensação que permitiram a aquisição de áreas para parques e até a reforma de

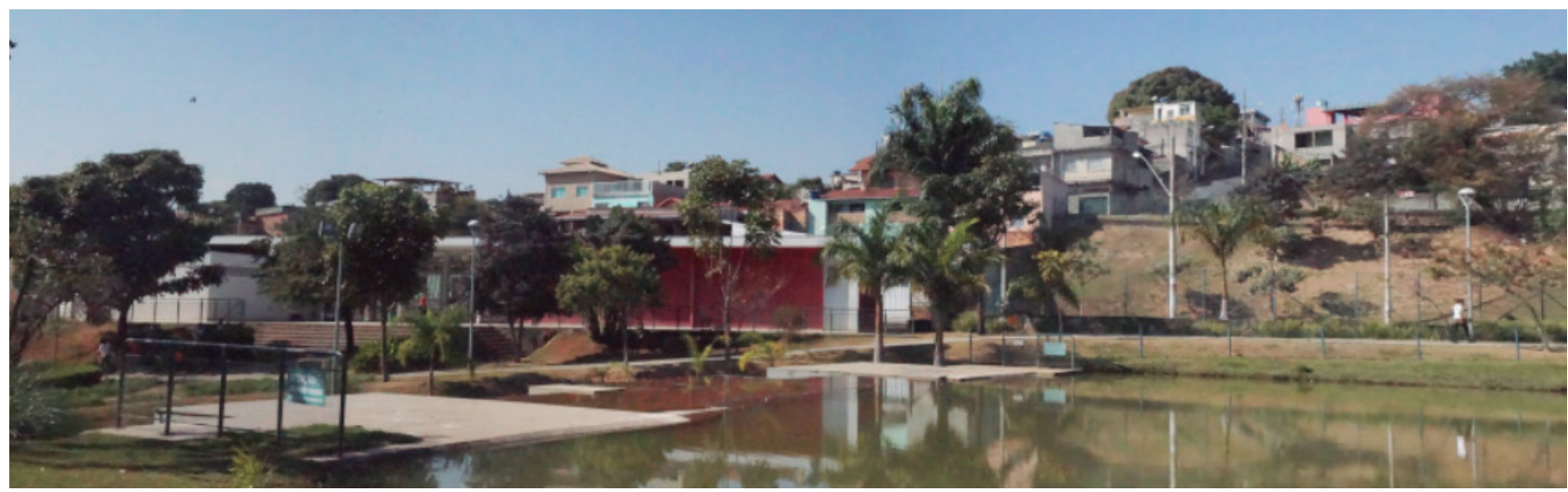

Figura 10 - Parque Nossa Senhora da Piedade, Belo Horizonte. Foto: Francine Sakata 2017.

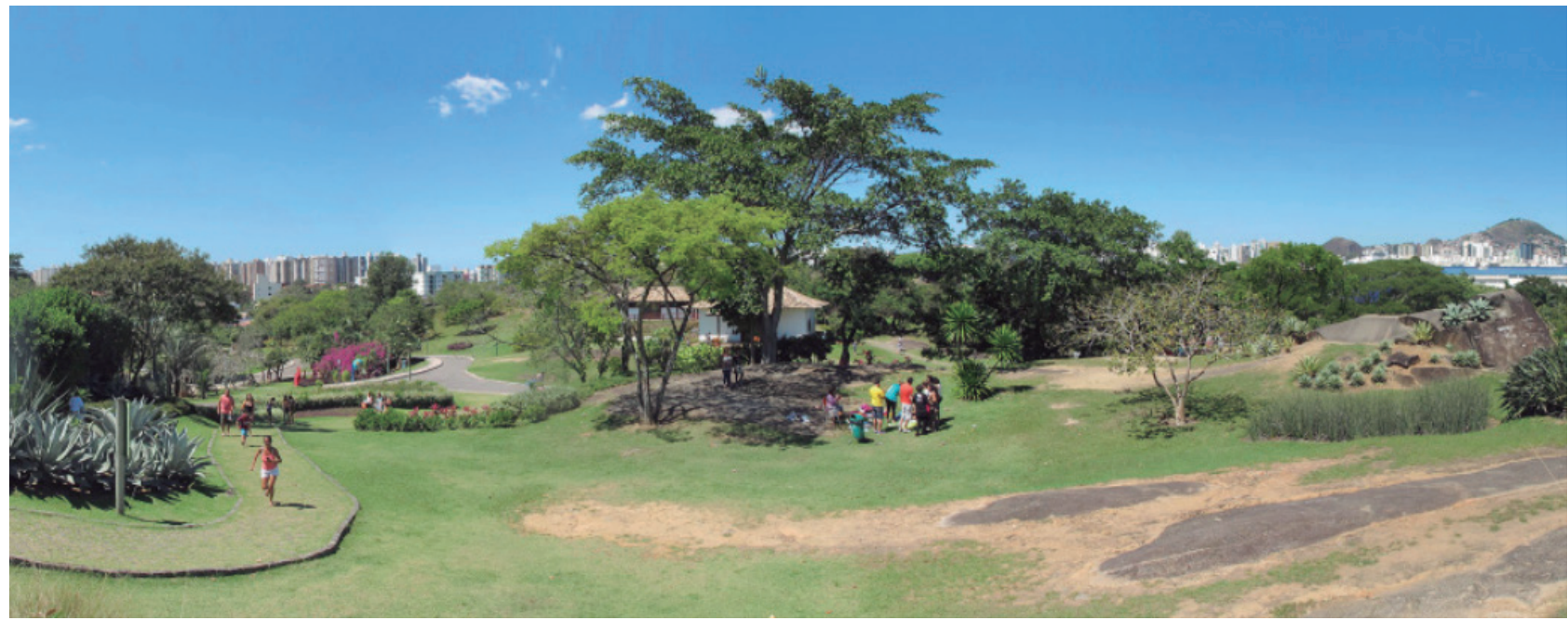

Figura 11 - Parque da Pedra da Cebola, em Vitória. Foto: Francine Sakata, 2014 
parques urbanos existentes, caso do Parque da Pedra da Cebola, em Vitória (Figura 11).

\section{Novo Conceito para Parque Urbano}

Em 2001, a publicação Parques urbanos no Brasil (MACEDO; SAKATA, 2001), feita no âmbito da Arquitetura e do Urbanismo, definiu parques urbanos como espaços livres nas cidades, com dimensões generosas, destinados à fruição social - passeio, contemplação, convivência, recreação infantil e esporte. Complementarmente, definiu-os como espaços urbanos estruturados pela vegetação, pela água, pelo relevo ou por todos esses elementos combinados, e que eram considerados parques por seu papel de lazer e práticas sociais.

O papel do parque como área de conservação ambiental poderia ser acrescentado a esses anteriormente mencionados. A combinação do papel de lazer com o de conservação é conveniente e benéfica para ambos e foi a grande contribuição do século XX para o conceito de parque.

Mas, a partir dos anos 2000, um número significativo de parques foi criado junto às malhas urbanas para atender prioritariamente às necessidades ambientais. Praticamente todos os novos parques produzidos a partir de 2000 foram descritos como parques sustentáveis. De fato, como espaços parcialmente permeáveis e arborizados, os parques cumprem funções ecológicas, contribuem para a drenagem urbana, manutenção do microclima e diminuição das ilhas de calor. Mesmo aqueles criados para a provisão de lazer em áreas carentes são apresentados como ações de cunho ambiental.

Com a criação dos parques naturais inseridos nas malhas urbanas, o parque urbano deixa de ser entendido como um espaço de lazer que pode ou não ser também um espaço de conservação. $O$ parque urbano passa a ser um espaço de conservação, que pode ou não contemplar atividades de lazer. Parques de conservação no meio urbano, bosques cercados e parques lineares são novas categorias de parques urbanos que prescindem do uso de lazer. A recreação, em alguns casos, é apenas possibilidade futura.
Entre os parques de conservação nas bordas das cidades, há muitos casos nos quais o lazer, quando introduzido, se restringe a trilhas, algumas vezes apenas nos limites externos. O Parque das Dunas (inaugurado em 2008) em Salvador (Figura 12) recebia visitantes para as trilhas mediante agendamento, em 2017. Há casos em que o acesso público é sazonal, dependendo das condições da gestão.

Na Zona Oeste do Rio de Janeiro, o Parque Natural Municipal do Mendanha (inaugurado em 2008), foi criado em uma gleba de $6.500 .000 \mathrm{~m}^{2}$ que pertencia à Companhia Bangu de Desenvolvimento e Participações e, em 2018, sofre ainda pressão pela ocupação por moradias em sua área, ameaçando a integridade do parque.

Os bosques cercados são casos similares, de menor porte. No setor sul da cidade de Curitiba, a partir de 2010, alguns bosques em terrenos públicos, em bairros mais pobres, foram cercados e tiveram o uso público vetado. Como o poder público em Curitiba é mais rigoroso com a categorização dos espaços livres, esses bosques não foram considerados parques, mas Bosques de Conservação da Biodiversidade Urbana (BCBUs). A municipalidade implantou calçadas em torno da área, do lado de fora da cerca, para que as pessoas pudessem apreciar o bosque durante a caminhada (Figura 13). Essa nova categoria, que "tem como objetivo a preservação de bancos genéticos", contorna as dificuldades imediatas de gestão desses espaços.

Bosques em bairros mais pobres são frequentemente vistos como depósitos de lixo e entulho, abrigos para marginais e invasões por construções. Cercada, a área cumpre funções ambientais e requer menos vigilância e manutenção, mas se torna um encrave urbano.

Entre 2000 e 2017, a prefeitura de Curitiba também implantou parques lineares, inclusive junto de conjuntos habitacionais, com a remoção parcial ou integral de favelas. Alguns contam com trechos com larguras generosas e equipados para o lazer como parques tradicionais. E há aqueles que são mais estreitos, e que não proporcionam ao visitante a sensação de isolamento do meio urbano, que é característica dos parques. Esses foram denominados pela prefeitura como parques lineares e têm características 


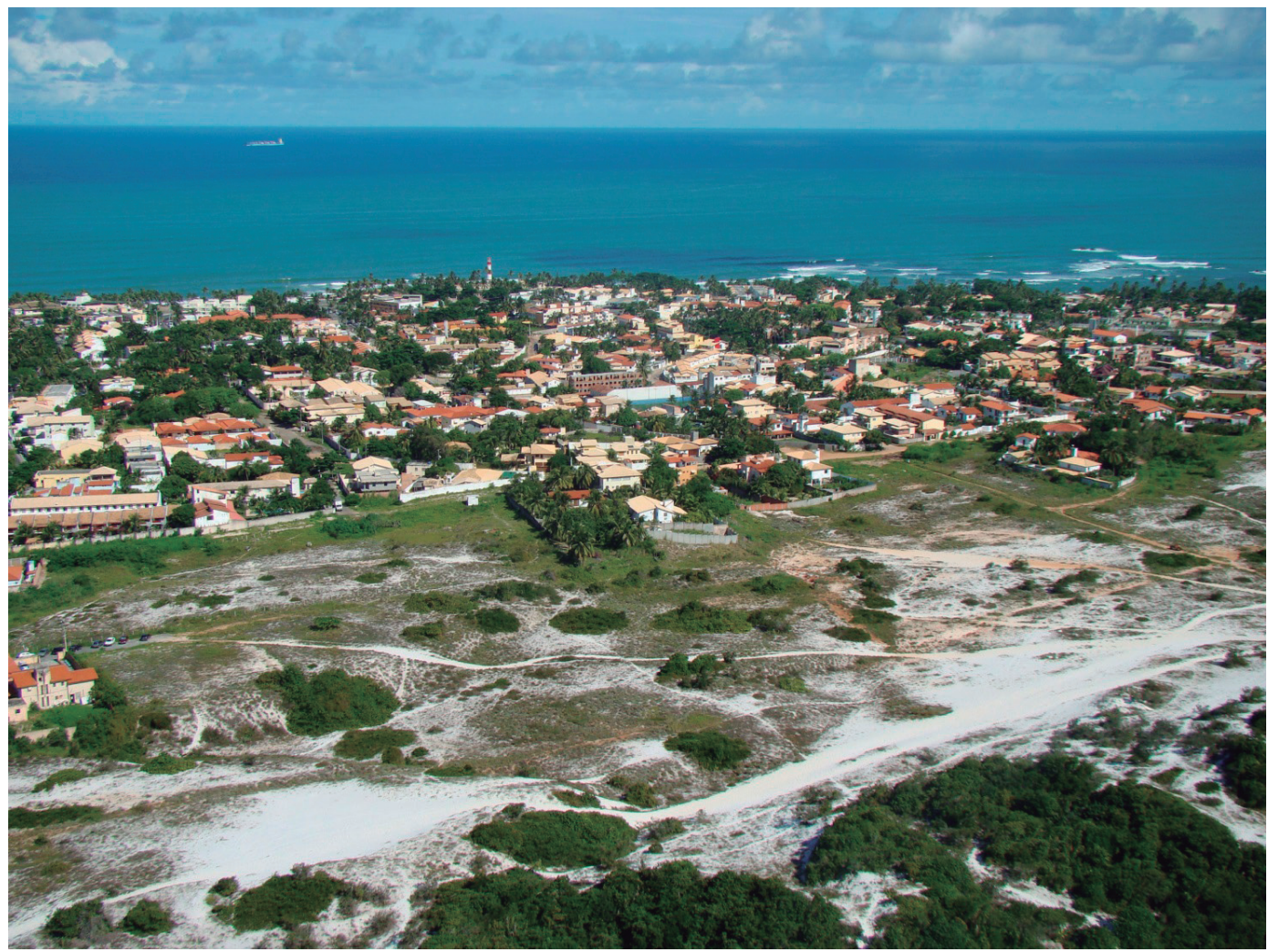

Figura 12 - Parque das Dunas, em Salvador. Foto: Silvio Macedo, 2010

que os aproximam das praças ou de outras categorias de espaços livres, mas não exatamente dos parques.

A Secretaria de Habitação paulistana projetou e implantou muitos espaços livres próximos de conjuntos de moradia popular. A denominação parque era dada quando a gestão era transferida, administrativamente, para a Secretaria do Verde e Meio Ambiente (SVMA) (GALENDER; CAMPOS, 2014). Esses parques não podem ser cercados porque os espaços têm relação muito próxima com vias e habitações, e a população precisa cruzá-los intermitentemente. Isso subverteu o conceito de parque utilizado pela Prefeitura de São Paulo, que os definia como áreas verdes cercadas, com regras e horários de funcionamento.

Para que essas obras fossem concretizadas, foram necessárias articulações intersecretariais e com as concessionárias estaduais - que foram facilitadas pela existência de um programa político. A criação da figura dos parques lineares pela SVMA foi crucial para que esses espaços pudessem ser gerados.

A qualificação de áreas livres em conjuntos habitacionais em vizinhanças de renda baixa é uma novidade no Brasil nos anos 2000 e, apesar dos esforços, ainda é pontual. Em geral, erguiam-se conjuntos habitacionais em bairros distantes, sobre extensas áreas livres não qualificadas, que com o tempo foram ocupadas por estacionamentos ou varais ou cercadas e privatizadas. Em favelas de bairros mais centrais e densos, quando se faz uma remoção seja para a construção de um conjunto habitacional ou para abrir o curso do rio - a implantação de áreas de lazer qualificadas é um modo de tentar garantir que o espaço não volte a ser ocupado por moradias precárias. 


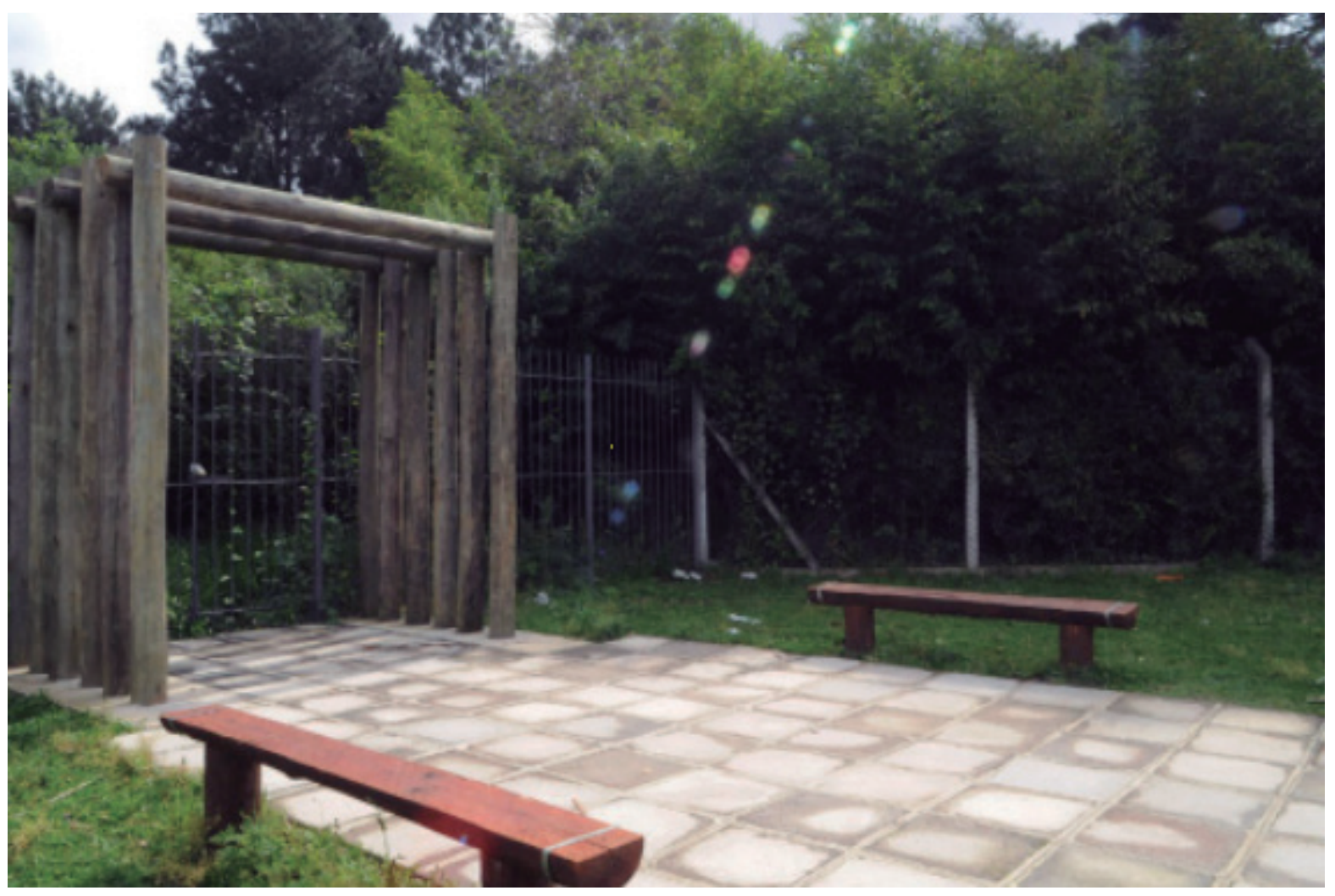

Figura 13 - Bosque de Conservação da Biodiversidade Urbana (BCBU)

Foto: Everson Brassan, 2014.

Os problemas de manutenção nessas áreas são visíveis. É comum haver pisos e mobiliários quebrados, pontes inacabadas, lixo e água acumulada. Ao mesmo tempo, o uso é intenso e as crianças têm onde brincar. A gestão desses espaços é um grande desafio para os próximos anos. É preciso reconhecer que não são apenas espaços de um bairro pobre, mas espaços da cidade, tão importantes quanto os demais.

Podemos desconsiderar que bosques cercados sejam parques, mesmo quando recebem essa denominação. Podemos mesmo desconsiderar que parte dos parques lineares sejam parques, especialmente quando muito diminutos. Mas existe um grande conjunto de áreas denominadas parques, em meio urbano, delimitadas com foco na conservação e não no lazer urbano, que nos obrigam a ampliar o conceito de parque urbano de forma que ele acolha essas novas figuras. Assim, o parque urbano do início do século XXI é um espaço livre público estruturado para a preservação ambiental ou para o lazer ou, como é sempre mais desejável, para ambas as funções.

Nas franjas das zonas norte e sul de São Paulo, existem bairros populosos entremeados por encostas da serra (ao norte) e braços das represas (ao sul), em urbanização fragmentada, com vias de acesso tortuosas e mal servidas por transporte e outras redes de infraestrutura. A relação da população com a natureza é contraditória: ao mesmo tempo, sua proximidade é motivo de orgulho e grande incômodo, pois faltam serviços urbanos. Nesse contexto, os parques criados como UCs não são simulacros da natureza no ambiente citadino, são a própria natureza e a ausência do urbano, no que ela tem de majestoso e de incômodo. Não está claro ainda como deve ser a gestão desses parques. 


\section{Considerações Finais}

Os parques se proliferaram nesse contexto de transformações urbanas e nova legislação ambiental, muitas vezes como meio de preservação de recursos naturais existentes, outras vezes para cumprir, simultaneamente, os papéis de conservação de recursos e provisão de espaços de lazer e esporte, valorizando os bairros que recebem novos empreendimentos imobiliários.

No período de 2000 a 2017, observou-se que ao mesmo tempo em que se construíam cidades fragmentadas - com loteamentos fechados para camadas de alta, média e baixa renda (caso de muitos conjuntos do Programa MCMV) - e condomínios de torres de apartamentos com térreos equipados com piscinas, playgrounds e quadras, os espaços públicos passaram a ser demandados ainda mais, tanto para usos tradicionais como para novos usos - de carnavais de rua a rondas noturnas de grupos de ciclistas. Corridas de rua ganharam adeptos; o número de animais domésticos, especialmente cães, aumentou; a população exige passeios, parques, calçadões e ciclovias. Os espaços livres nunca estiveram tão cheios.

Grandes parques foram construídos entre 2000 e 2017 no país, como o da Juventude (2007) e o do Povo (2008) em São Paulo; o Mangal das Garças (2005) em Belém; o Madureira (2012/2015) no Rio de Janeiro. Também foram feitos muitos parques com projetos mais simples, como aqueles em torno da Represa de Guarapiranga, que aproveitam ao máximo os elementos naturais existentes. Nesses, a facilidade de execução e o baixo custo são privilegiados como critérios de projeto. Muitos se articulam por caminhos que envolvem os bosques já formados, com bancos, brinquedos e os onipresentes "aparelhos de ginástica para a terceira idade". Nesses casos, quando realizados os projetos de plantio, são discretos, pontuais e complementares.

Esses parques mais simples e em áreas periféricas fazem parte da história dos parques, do paisagismo e do urbanismo brasileiro, mas são fenômenos recentes, de grande escala e relevância para muitas cidades brasileiras. Por um lado, são espaços de uso efetivo ou com potencial de virem a ser usados mas, por outro, espelham o relativo despreparo dos quadros funcionais das prefeituras para implantá-los e geri-los. É possível que sua existência contribua positivamente para a mudança desse quadro.

Os parques implantados confirmam que a cultura de uso e manutenção dos parques urbanos possui, no Brasil, tradição elitista, isso é, das rendas mais altas serem servidas por equipamentos de melhor qualidade. O novo conjunto, que inclui locações de rendas mais baixas, é, portanto, um passo importante para que se tornem mais democráticos e inclusivos. Pode-se esperar que as gerações que crescerem utilizando os parques se comprometam com sua defesa e manutenção. Se muitos desses parques não forem mais do que estratégias de proteção efetiva de várzeas e encostas, para impedir ocupações inadequadas e ilegais, é possível que sejam reservados, qualificados e abertos à efetiva utilização da população no futuro.

Ter esse expressivo conjunto de parques significa o passo possível, oportuno e importante no sentido de aprimorar o sistema de espaços livres urbanos dessas cidades. Tal passo só foi possível pelo entendimento do papel dos parques implantados nas décadas anteriores. A intensa utilização desses - cotidiana ou esporádica - na segunda metade do século XX mostrou à população, aos políticos e agentes imobiliários seus múltiplos potenciais.

Nos anos 2000, o poder público, devido à impossibilidade de agir conforme a real necessidade e demanda da população e à necessidade de capturar recursos de fontes variadas, não age pautado pelo planejamento urbano, mas pelo aproveitamento das oportunidades. O fortalecimento do discurso ambiental - até por conta do aproveitamento de verbas provenientes de compensações ambientais - levou a função de recreação para segundo plano nos parques urbanos.

\section{REFERÊNCIAS BibLIOGRÁFICAS}

BARTALINI, Vladimir. Parques públicos municipais de São Paulo: a ação da municipalidade no provimento de áreas verdes de recreação. 1999. Tese (Doutorado em Arquitetura e Urbanismo) - Faculdade de Arquitetura e Urbanismo, Universidade de São Paulo, São Paulo, 1999. BRASIL. Casa Civil. Lei $n^{\circ} 12.727$, de 17 de outubro de 2012. Altera a Lei $n^{\circ} 12.651$, de 25 de maio de 2012, que dispõe sobre a proteção da vegetação nativa; altera as Leis $n^{\circ}$ s 6.938 , de 
31 de agosto de 1981, 9.393, de 19 de dezembro de 1996, e 11.428, de 22 de dezembro de 2006; e revoga as Leis $\mathrm{n}^{\circ}$ s 4.771, de 15 de setembro de 1965, e 7.754, de 14 de abril de 1989, a Medida Provisória ${ }^{\circ} 2.166-67$, de 24 de agosto de 2001, o item 22 do inciso II do art. 167 da $n^{\circ} 6.015$, de 31 de dezembro de 1973, e $\$ 2^{\circ}$ do art. $4^{\circ}$ da $101 n^{\circ} 12.651$, d da Lein 612. maio de 2012. Diário http://aiba.org.br/wp-content/uploads/2014/10/Lei-12727-2012-Codigo-florestal.pdf. Acesso em: 11 jun. 2019

COELHO, Leonardo Loyolla. Compensação ambiental: uma alternativa para viabilização de espaços livres públicos para lazer e convívio na cidade de São Paulo. 2008. Dissertação (Mes trado em Arquitetura e Urbanismo) - Faculdade de Arquitetura e Urbanismo, Universidade de São Paulo, São Paulo, 2008

CURITIBA. Mais sete áreas do Município serão transformadas em bosques de conservação. Prefeitura de Curitiba, Curitiba, 1 out. 2014. Disponível em: https://www.curitiba.pr.gov. $\mathrm{br} /$ noticias/mais-sete-areas-do-municipio-serao-transformadas-em-bosques-de-conservacao/34296. Acesso em: 1 jun. 2015.

CUSTÓDIO, Vanderli (org.). Relatório Oficina Quapá-SEL II Rio de Janeiro-RJ 05 e 06 de dezembro de 2016. São Paulo: Quapá, 2016.

FORTALEZA. Decreto $n^{\circ} 13.286$, de 14 de janeiro de 2014. Dispõe sobre a criação e regulamentação dos Parques Urbanos das Lagoas de Fortaleza. Diário Oficial de Fortaleza, Fortaleza, 21 jan. 2019. Caderno 1, p. 5.

GALENDER, Fany; CAMPOS, Ana Cecília M. de Arruda. Ações públicas em São Paulo voltadas para recuperação dos corpos d'água: percepção e apropriação. In: SEMINÁRIO NACIONAL SOBRE O TRATAMENTO DE ÁREAS DE PRESERVAÇÃO PERMANENTE EM MEIO URBANO RESTRIÇÕES AMBIENTAIS AO PARCELAMENTO DO SOLO, 3., Belém, 2014. Anais [...]. Belém APPURBANA, 2014. p. 1-20.

IBAMA. Lei da vida: lei dos crimes ambientais: Lei $n^{\circ} 9.605$, de 12 de fevereiro de 1998 Decreto $\mathrm{n}^{\circ}$ 6.514, de 22 de julho de 2008. Brasília, DF: Ibama, 2014

MACEDO, Silvio Soares; SAKATA, Francine. Parques urbanos no Brasil. São Paulo: Edusp 2001.

PEGORARO, Rafael Lopez. Transformação urbana no Brasil: estudo de cinco centros urbanos. Relatório científico final. São Paulo: Fapesp, 2017.

RIBEIRO, Victória Mendes. Uso e ocupação recente de áreas pouco adensadas e suas áre as livres no espaço urbano brasileiro: o caso das cidades de Anápolis, Uberlândia, Palmas, Brasília, Cuiabá e Goiânia, estudadas pela Rede Nacional de Pesquisa Quapá-SEL. Relatório

Brasília, Cuiabá e Goiânia, estudadas pela
científico final. São Paulo: FAUUSP, 2018.

RIO DE JANEIRO (Município). Secretaria Municipal de Meio Ambiente. Áreas protegidas. Rio Prefeitura, Rio de Janeiro, 26 jan. 2010. http://alvaraja.rio.rj.gov.br/web/smac/exibeconteudo?id=2812667. Acesso em: 15 jul. 2019.

SAKATA, Francine. Parques urbanos no Brasil 2000-2017. 2018. Tese (Doutorado em Arquitetura e Urbanismo) - Faculdade de Arquitetura e Urbanismo, Universidade de São Paulo, São Paulo, 2018

SOUZA, Conrado Blanco de. APPs fluviais urbanas e sistemas de espaços livres: uma análise da influência do Código Florestal na forma das cidades brasileiras. 2015. Dissertação (Mestrado em Arquitetura e Urbanismo) - Faculdade de Arquitetura e Urbanismo, Universidade de São Paulo, São Paulo, 2015
SOUZA, Roberto Sakamoto Rezende de. O papel das leis e das instituições para a conservação da diversidade ambiental e cultural na Baixada Santista. 2018. Tese (Doutorado em Arquitetura e Urbanismo) - Fa Paulo, São Paulo, 2018.

TRIGUEIRO, Aline; LEONARDO, Flavia Amboss Merçon. A gestão política do meio ambiente na cidade de Vitória-ES: reflexões sobre a criação de parques naturais e áreas verdes. In: $S E-$ MINÁRIO NACIONAL DE PÓS-GRADUAÇ̃̃O EM CIÊNCIAS SOCIAIS DA UFES, 1 , Vitória. Anais [...]. Vitória: UFES, 2011. p. 1-24.

WHATELY, Marussia; SANTORO, Paula Freire; GONÇALVES, Bárbara Carvalho; GONZATTO Ana Maria. Parques urbanos municipais de São Paulo: subsídios para a gestão. São Paulo: Instituto Socioambiental, 2008.

Francine Gramacho Sakata

Universidade de São Paulo, Faculdade de Arquitetura e Urbanismo (FAU-USP)

Rua do Lago, 876- Butantã, São Paulo - SP, 05508-080

Orcid: https://orcid.org/0000-0003-2633-1791

francinesakata@gmail.com

Fabio Mariz Gonçalves

Universidade de São Paulo, Faculdade de Arquitetura e Urbanismo

(FAU-USP)

Rua do Lago, 876- Butantã, São Paulo - SP, 05508-080

Orcid: https://orcid.org/0000-0002-3184-9985

fabiomgoncalves@usp.br

\section{Agradecimentos}

A Silvio Soares Macedo.

\section{Nota do Editor:}

Submetido em: 19/03/2019

Aprovado em: 10/07/2019

Revisão do texto: Tikinet 